\title{
Application of 8d methodology - an effective problem solving tool in automotive industry
}

\author{
Cristina - Florena BANICA, Nadia BELU* \\ University of Pitesti, Pitesti, Romania \\ ${ }^{*}$ Corresponding author e-mail: nadia.belu@upit.ro \\ Article history \\ Received 20.06.2019 \\ Accepted 15.08 .2019 \\ DOI https://doi.org/10.26825/bup.ar.2019.005
}

\begin{abstract}
Quality plays an important role in an organization from automotive industry to become more efficient and effective in the global market. In this sector there are many requirements to problem solving process using standardized methodologies, according to international standards. 8D methodology has become very popular among manufacturers because it is effective to use. The aim of this paper is to apply the $8 \mathrm{D}$ methodology and to analyze its effectiveness. In order to apply the $8 \mathrm{D}$ methodology and to analyze its effectiveness a case study was conducted in a company from automotive industry. The results can be used by the management in continuous improvement as additional motivation for more effective use.
\end{abstract}

Keywords: 8D, QRQC methodologies, problem solving, quality improvement

\section{Introduction}

The automotive industry is one of the most important sectors of the global economy. Improvement in quality of product and process is necessary for any company from this sector in order to survive and to grow in competitive market. For this, problem solving techniques are required by the quality management in the automotive industry. Regarding quality management, problem solving is fostered by the Measurement Systems Analysis work group [1], [2] and the standard IATF 16949:2016 of International Automotive Task Force [3], [4], [5] for automotive industry. The goal of this QMS standard is the development of a quality management system that provides for continual improvement, emphasizing defect prevention and the reduction of variation and waste in the supply chain. According this standard, the organization shall have a documented process for problem solving including: root cause analysis, methodology used, analysis and results. One of the methods used is $8 \mathrm{D}$ methodology based on Quick Response Quality Control (QRQC) tool. The 8D method (also called G8D, Global 8D, TOPS $8 \mathrm{D}$ ) is one of the most widely used problem-solving tools related to nonconformities reoccurrence prevention in the manufacturing process, commonly used for complaints management in automotive industry. It consist of 8-steps to be followed by quality improvement team for problem solving as well as for product and process improvement [6]. QRQC is described as a quick and comprehensive problem-solving process for the industrial and services sectors that ensures problems 
do not reoccur while at the same time establishing dynamics of continuous improvement and modifying management culture. This paper presents the $8 \mathrm{D}$ methodology through case study for improving of quality in the automotive industry for powder painting processes.

\section{8d methodology}

The $8 \mathrm{D}$ methodology is effective in developing proper actions in order to eliminate root causes and in implementing the permanent corrective actions to eliminate them. It also contributes to explore the system of control that allowed the escape of the problem [7], [8], [9]. The 8D methodology involves teams working together in order to solve quality problems, using a structured 8 phases, table 1 [9]. QRQC is a quality tool support of the $8 \mathrm{D}$ methodology. The basis of QRQC is the quick answer to a quality / manufacturing issue no matter if it's an external / internal customer or a supplier.

Table 1. Phases of 8D Methodology

\begin{tabular}{|c|c|c|}
\hline No. & $\begin{array}{l}\text { Phase of the } \\
\text { 8D } \\
\text { methodology }\end{array}$ & Description \\
\hline 1 & $\begin{array}{l}\text { Problem } \\
\text { description }\end{array}$ & $\begin{array}{l}\text { To identify the problem, the } 8 \mathrm{D} \text { team tries to acquire more information as possible from the } \\
\text { customer, which constitutes the first analysis performed in the problem-solving process. The } \\
\text { location and nature of problem must be given along its effects. Another important information } \\
\text { is whether the problem included is intermittent or whether it could happen on similar products } \\
\text { or processes. While depicting the problem, the } 5 \mathrm{~W} \text { (Who, What, Where, When, Why) And } 2 \mathrm{~h} \\
\text { (How, How Many/Much) method should be used, where the accompanying inquiries must be } \\
\text { addressed completely and efficiently and WHY for each question. The responses to these } \\
\text { inquiries help us clarify the background and connections. }\end{array}$ \\
\hline 2 & $\begin{array}{l}\text { Reference to } \\
\text { similar } \\
\text { products }\end{array}$ & $\begin{array}{l}\text { This phase is done with the purpose to detect other products with the same nonconformity risk. } \\
\text { The subsequent aspects must be taken into consideration: the list of the detected problems, the } \\
\text { place of their detection, the technological process in question, what other parts are realised in } \\
\text { the same process, whether here is also a nonconformity risk in what they are concerned, where } \\
\text { these parts are used. }\end{array}$ \\
\hline 3 & $\begin{array}{l}\text { The first } \\
\text { analysis }\end{array}$ & $\begin{array}{l}\text { In this step identification of genuine cause and determination of restorative measures aimed to } \\
\text { solve the problem permanently. To obtain root cause, all the causes which are found wrong are } \\
\text { wiped out. Both the manufacturing process and the control process are taken into account. The } \\
\text { point where the problem has escaped the control system (escape point) must be sought for and } \\
\text { detected, as well as the moment when it could have been detected. }\end{array}$ \\
\hline 4 & $\begin{array}{l}\text { Immediate } \\
\text { action plans }\end{array}$ & $\begin{array}{l}\text { Measurements are carried by two means, it is carried out by } \\
\text { - means of control devices (digital data and outputs are associated to computers) } \\
\text { - means is carried out by using statistical methods: statistical Process Control, Process } \\
\text { Capability (cp), Process Capability index (Cpk), histograms, and Pareto diagrams. }\end{array}$ \\
\hline 5 & $\begin{array}{l}\text { Final } \\
\text { analysis }\end{array}$ & $\begin{array}{l}\text { This phase is carried out with the purpose of obtaining a real and complete of the situation in } \\
\text { order to find the root causes and to decide the optimum actions required for the treatment of the } \\
\text { causes. This phase aims at finding the causes, not the solutions. Final analysis implies a } \\
\text { detailed analysis of the data. For this purpose, multidisciplinary team work is used; such teams } \\
\text { go on the respective site in order to understand the problem. It must be noted that most of the } \\
\text { complex problems usually have more than one root cause that interact with each other. } \\
\text { The validity of these causes should be verified because it is essential to treat the real causes. }\end{array}$ \\
\hline 6 & $\begin{array}{l}\text { Final action } \\
\text { plans }\end{array}$ & $\begin{array}{l}\text { Establishing an implementation plan for permanent corrective actions. Permanent actions are } \\
\text { analysed and applied in order to prevent the recurrence of the problem permanently. The final } \\
\text { elimination action must be focused on the real main root causes (phase 5) and on the escape } \\
\text { point (phase 3). Thus the aim is to solve both the root causes of the problem, as well as the root } \\
\text { causes of the failure to detect the problem. In order to prevent the recurrence of the problem, a } \\
\text { number of actions are applied: updating procedures, training the personnel. }\end{array}$ \\
\hline 7 & $\begin{array}{l}\text { Confirmation } \\
\text { of the action } \\
\text { plans }\end{array}$ & $\begin{array}{l}\text { Phase } 7 \text { of the } 8 \mathrm{D} \text { method is very important due to the fact that it allows for the closing of the } \\
\text { action plans. The effectiveness of the final action plans is checked. It is a key stage meant to } \\
\text { avoid the recurrence of the quality problem. } \\
\text { The Supplier Quality Service will require evidence of the effectiveness of the action plans and, } \\
\text { in order to be able to validate the } 8 \mathrm{D} \text {, may also perform an audit if it finds that the effectiveness } \\
\text { of such actions is not trustworthy. So long as the effectiveness of the actions is not proven, the } \\
\text { supplier should make sure that it supplies } 100 \% \text { good parts by carrying out checks. } \\
\text { The Supplier Quality Service will be notified in what the results of such checks are concerned. }\end{array}$ \\
\hline 8 & $\begin{array}{l}\text { Preventing a } \\
\text { recurrence of } \\
\text { the problem }\end{array}$ & $\begin{array}{l}\text { In this step the } 8 \mathrm{D} \text { team analyse whether the corrective action executed would avoid or enhance } \\
\text { the quality of similar products and processes. }\end{array}$ \\
\hline
\end{tabular}




\section{Case study}

In our paper, we have focused on the use of $8 \mathrm{D}$ methodology to solve the various problems encountered in the production of automotive components. In our case it was a problem that occurred during powder painting processes, Figure 1. The problem was identified in the Quality Wall by an operator. Powder painting is the application of solid powder to create industrial coatings.

The powder is applied by an electrostatic process to a substrate, usually metal, and acquires excellent properties when the particles are heated and polymerise on the substrate. This method is widely used to protect surfaces and ensure a pristine finish that cannot be achieved with regular paints.

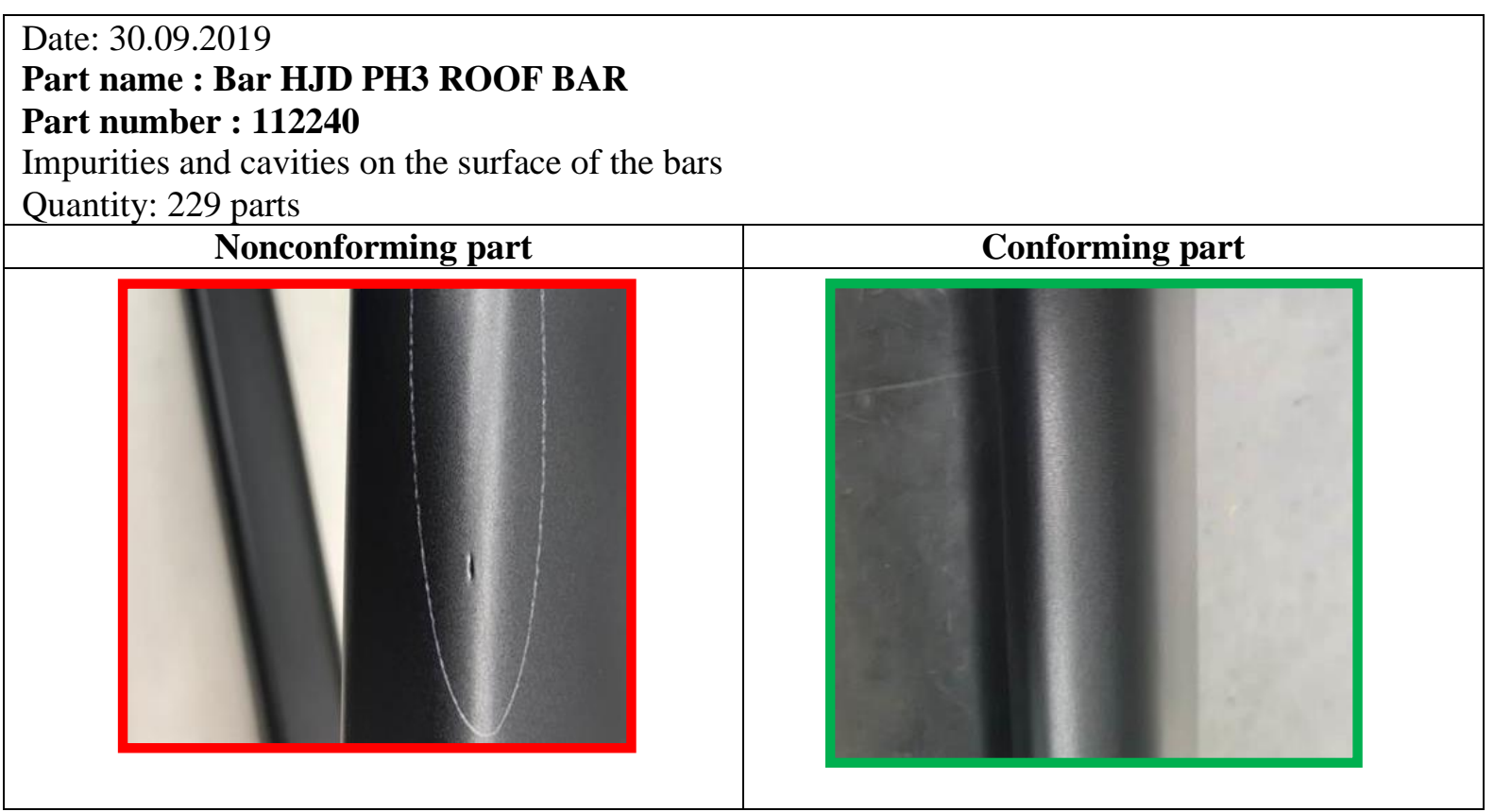

Figure 1. Nonconforming painted parts

This problem was solved by using $8 \mathrm{D}$ and QRQC methods. The stages of the methodologies are shown below in the table 2 - 9.

Table 2. Problem description

\begin{tabular}{|c|c|c|c|}
\hline Reference Number: 112240 & Issued by: & \multicolumn{2}{|c|}{ Validated by : } \\
\hline Parts name: Bar HJD PH3 ROOF BAR & Function & \multicolumn{2}{|c|}{ Function } \\
\hline & \begin{tabular}{|l|} 
Date \\
30.09.2019
\end{tabular} & \multicolumn{2}{|c|}{ Date: 30.09.2019 } \\
\hline 1. Details of the problem & \multicolumn{3}{|l|}{ Date: } \\
\hline Report N ${ }^{\circ}: 6102-3339$ & \multicolumn{3}{|c|}{ Affected quantity: 229} \\
\hline \multicolumn{4}{|c|}{$\begin{array}{l}\text { Description: Impurities and cavities on the surface of the bars } \\
\text { Why is it a problem? Visual problem. } \\
\text { Who detected the problem? Customer } \\
\text { Who generated the problem? Supplier } \\
\text { How was the problem detected? Customer production line visual control } \\
\text { When did the problem occur? 30.09.19 } \\
\text { When the part has been produced? } 18.09 .19 \\
\text { How many? } 128 \text { Nonconforming bars and } 229 \text { Nonconforming painted bars }\end{array}$} \\
\hline & & Yes & No \\
\hline & Recurrence & & $\sqrt{ }$ \\
\hline
\end{tabular}


Table 3. Reference to similar products

\begin{tabular}{|c|c|c|c|}
\hline \multicolumn{4}{|c|}{ 2. Other concerned similar products? } \\
\hline \multicolumn{4}{|c|}{ Can this defect appear on other similar parts? } \\
\hline & Yes & No & Comments / Results \\
\hline Other pieces & $\sqrt{ }$ & & \\
\hline Products same family & $\sqrt{ }$ & & \\
\hline Left / Right & $\sqrt{ }$ & & \\
\hline Symmetric product & & $\sqrt{ }$ & \\
\hline Front / Back & & $\sqrt{ }$ & \\
\hline Others & & $\sqrt{ }$ & \\
\hline
\end{tabular}

Table 4. The first analysis

\section{First analysis}

At this step we used QRQC methodology, a tool for quick resolution no repletion the problems. It uses tools as

Ishikawa diagram and 5 Why.

$5 \mathrm{~W} 1 \mathrm{H}$ method allows the problem to be broken down and determine a root cause.

\begin{tabular}{|l|l|}
\hline \multicolumn{1}{|c|}{ Description of the problem } & \multicolumn{1}{c|}{ Results } \\
\hline What is the problem? & Impurities and cavities on the surface of the bars \\
\hline Who detected the problem? & Operator \\
\hline Where was the problem detected? & Quality Wall \\
\hline When was the problem created? & 30.09 .2019 \\
\hline How many? & 229 parts \\
\hline Why is it a problem? & The client's requirements are not respected \\
\hline
\end{tabular}

The cause of this problem will be further investigated using the Ishikawa diagram, figure 2 (which is also named Fishbone). That constitutes a significant point in the topic of methods for problem solution is actuating as a key tool to solve assembly and maintenance troubles in the automotive and transport sectors. It is used to identify possible causes of a specific problem.

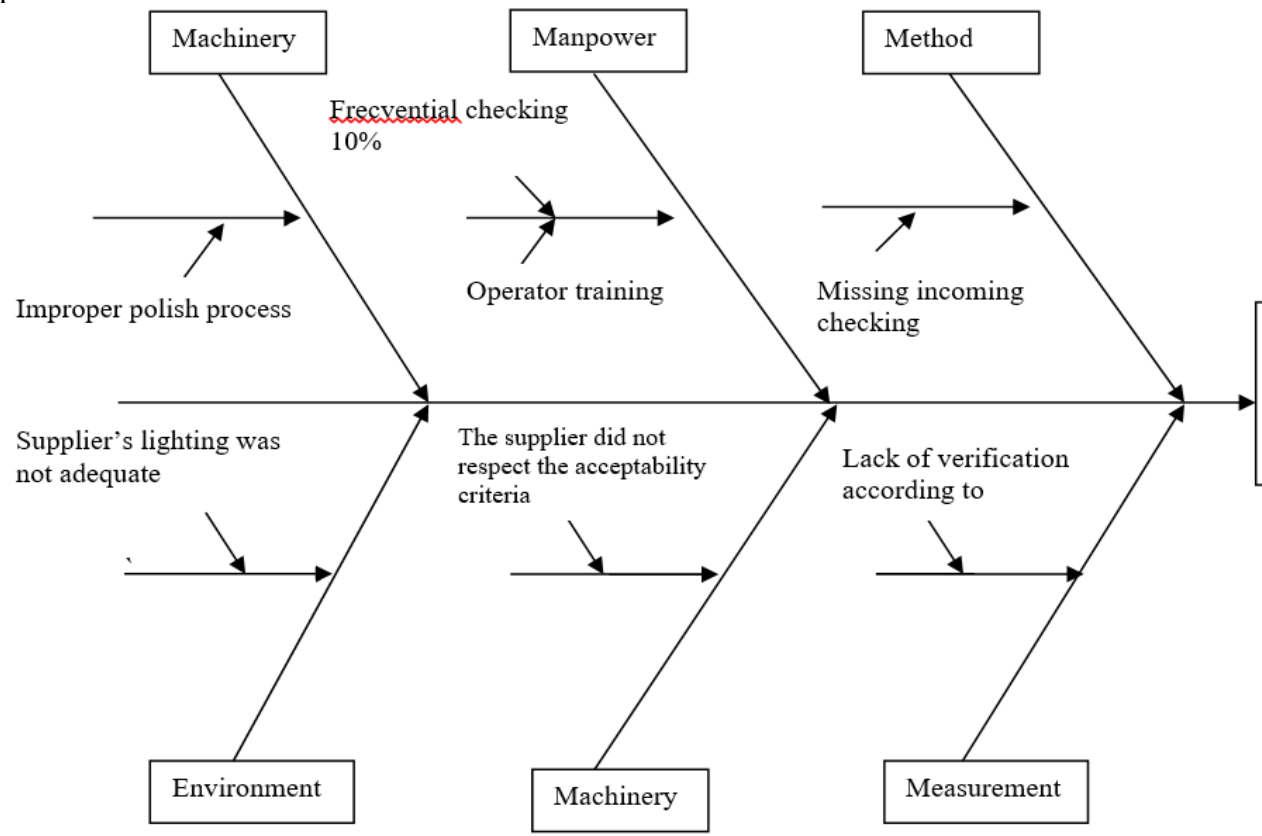

Impurities and cavities on the surface of the bars

Figure 2. Fishbone for impurities and cavities on the bars surface 
5 Why it is a simple approach to explore the causes until the root cause is reached.

\begin{tabular}{|c|c|c|}
\hline Why? & Why? & Why? \\
\hline $\begin{array}{l}\text { Parts have small scratches, which } \\
\text { can be seen after painting process. }\end{array}$ & $\begin{array}{l}\text { The raw material had scratches, which } \\
\text { stay even after the surface treatment } \\
\text { processes. The parts with small surface } \\
\text { failures were not detected. }\end{array}$ & $\begin{array}{l}\text { Operators were not enough } \\
\text { informed about the surface } \\
\text { criteria. }\end{array}$ \\
\hline \multicolumn{3}{|c|}{ The non-detection actions for the pallet support product in the table 2 are identified below. } \\
\hline \multicolumn{2}{|c|}{ Non-detection actions } & Department \\
\hline \multicolumn{2}{|c|}{ Elaboration of the pickling verification method } & Methods \\
\hline \multicolumn{2}{|c|}{ Instruction sheet for checking the bars support after pickling } & Methods \\
\hline \multicolumn{2}{|c|}{ Identification of the defect in critical board } & Quality \\
\hline \multicolumn{2}{|c|}{ Instruction sheet for checking rust on the bars support } & Methods \\
\hline
\end{tabular}

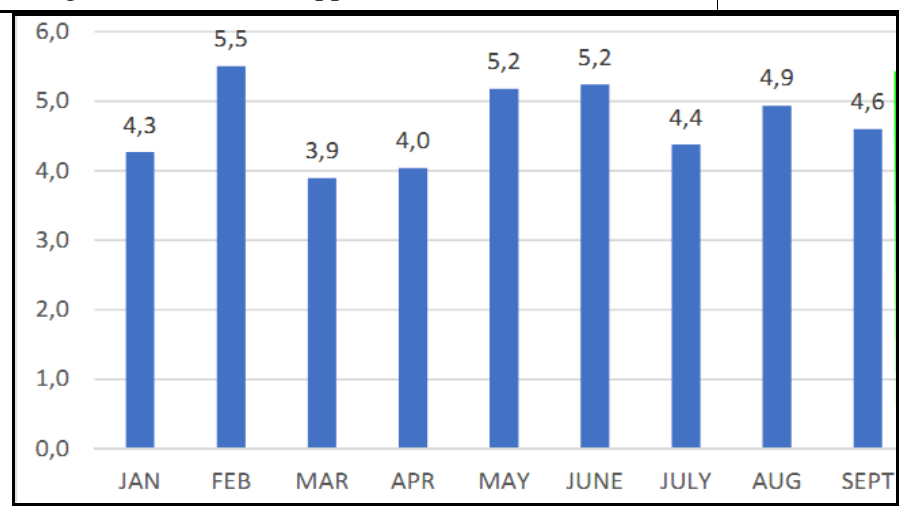

Figure 3. Failures evolution

Before the analysis, the average of the failures was 4.6, figure3, after the analysis the results obtained will be analyzed.

Table 5 Immediate action plans

\section{Immediate action plan}

Which are the actions began to prevent the delivery of not corresponding products to customer?

\begin{tabular}{|l|c|c|c|}
\hline & Actions & $\begin{array}{c}\text { Quantity } \\
\text { conform }\end{array}$ & $\begin{array}{c}\text { Quantity } \\
\text { Not conform }\end{array}$ \\
\hline During the manufacture process & & 0 & 0 \\
\hline Current stock & & 0 & 0 \\
\hline Stocking in Shop & & 0 & 0 \\
\hline Spare pieces & & 0 & 0 \\
\hline Others & & \\
\hline $\begin{array}{l}\text { How are OK products identified? } \\
\text { Labeled: Checked 100\% }\end{array}$ & \\
\hline Expedition date / Remarks & & \\
\hline
\end{tabular}

\section{Final analysis}

End date of analysis

Table 6 Final analysis

Indicate the real causes on the whole Process:

* Man, Material, Machine, Methods

* Who, Where, When, Why, How

* Changement de fabrication. Processus de Retouches

* Maintenance

\begin{tabular}{|l|c|c|}
\hline Causes: & Responsibility & Department \\
\hline Nonconforming self-control & D.G. & Production \\
\hline New products, undisclosed by operators & P.R. & Production \\
\hline $\begin{array}{l}\text { The hanging of parts on the carriers is nonconforming } \\
\text { The available conditioning does not protect the parts against } \\
\text { scratching due to contact between them }\end{array}$ & P.R. & Production \\
\hline The instruction sheet about the parts hanging is missing & P.R. & Production \\
\hline
\end{tabular}




\begin{tabular}{|c|c|c|}
\hline 6. Definitive action plans & & \\
\hline Actions & $\begin{array}{c}\text { Service / } \\
\text { Responsibility }\end{array}$ & Date \\
\hline Realization of a Quality Alert & Quality & W48 \\
\hline Sorting in the customer plant & Production & W48 \\
\hline Sorting in the logistics platform & Production & W48 \\
\hline Sorting in lorries being loaded or on the road & Production & W48 \\
\hline Training of the operators about the failures and the company control criteria & Production & W48 \\
\hline $\begin{array}{l}\text { Visual control and marking has been implemented after bending process to } \\
\text { increase awareness on surface failures at polishing operation }\end{array}$ & Production & W46 \\
\hline Training of the operators concerning the parts hanging on the carriers & Production & W48 \\
\hline $\begin{array}{l}\text { Visual control has been improved after painting process by adding } \\
\text { additional visual control }\end{array}$ & Production & W48 \\
\hline $\begin{array}{l}\text { Defining, with the customer, the conditionings to protect the parts during } \\
\text { transportation }\end{array}$ & Quality & W49 \\
\hline $100 \%$ Control and labeling of the first three deliveries & Production & W48 \\
\hline
\end{tabular}

Table 8 Confirmation of the action plans

\begin{tabular}{|c|c|c|}
\hline 7. Action Plans Confirmation & Validation date & 20.10 .2019 \\
\hline \multirow[t]{2}{*}{ The begun actions were confirmed like effectives? } & Yes & No \\
\hline & $\sqrt{ }$ & \\
\hline
\end{tabular}

Table 9 Preventing a recurrence of the problem

\begin{tabular}{|c|c|c|c|}
\hline \multirow{2}{*}{\multicolumn{4}{|c|}{\begin{tabular}{|l|l|} 
Preventing a recurrence of the problem & Closing Date: \\
After the update of the actions, the following subjects require one updated?
\end{tabular}}} \\
\hline & & & \\
\hline & Yes & Responsibility & Date \\
\hline All actions validated and put in place & $\sqrt{ }$ & Production & 04.11 .2019 \\
\hline Product FMEA and/or Process updated & $\sqrt{ }$ & Quality & 04.11 .2019 \\
\hline Control plan updated & $\sqrt{ }$ & Quality & 04.11 .2019 \\
\hline Update procedures & $\sqrt{ }$ & Production & 04.11 .2019 \\
\hline Instructions (control monitoring plans) & $\sqrt{ }$ & Production & 04.11 .2019 \\
\hline Specifications adapted (only in project) & $\sqrt{ }$ & & $\mathrm{n} / \mathrm{a}$ \\
\hline Product / process design guide updated (only in project) & $\sqrt{ }$ & & $\mathrm{n} / \mathrm{a}$ \\
\hline Lessons learned created and shared & $\sqrt{ }$ & & 04.11 .2019 \\
\hline $\begin{array}{l}\text { The audit performed by Quality and manufacturing at the } \\
\text { naintenance operation level } 1\end{array}$ & $\sqrt{ }$ & & \\
\hline $\begin{array}{l}\text { Each month, an information session on customer complaints and } \\
\text { nternal complaints will be organized within the welding workshop }\end{array}$ & $\sqrt{ }$ & & \\
\hline
\end{tabular}

The final stage of the $8 \mathrm{D}$ report aims to summarize all the experience and knowledge of the team, as well as the documentation used to prepare the $8 \mathrm{D}$ report. After taking the permanent corrective and preventive actions and closing the $8 \mathrm{D}$ activity through quality planning, the average of the failures reduces to 4.6 from 2.4 .

\section{Conclusions}

The 8D methodology used in this paper is an excellent tool for solving the problem as well as for preventing defects from reoccurring. It is practical and simple sheet, which use isn't allwasy easy. Appear as one of the basic problem solving methodology, 8D offers an essential solution from identifying the root cause until the implementation of preventive action. When solving a complaint, $8 \mathrm{D}$ reports are always demanded form suppliers. A future work can be suggested for other production 
cases in which the 8D methodology to be used like a support for Failure Mode \& Effect Analysis or Quality Assurance Matrix - tools for quality improvement in the automotive industry.

\section{References}

[1] Measurement Systems Analysis work group: Reference Manual Third Edition 2002 Daimler-Crysler. Ford Motor Company and General Motors, Copyright protected by AIAG, 2002.

[2] Suarez-Warden, F. \& González Mendívil, E., Problem solving in transference of procedural knowledge aided by AR to support aeronautical transportation decisions, Int $\mathbf{J}$ Interact Des Manuf 2018, 12: 337. https://doi.org/10.1007/s12008-017-0384-1.

[3] International Automotive Task Force. IATF 16949:2016 Automotive Quality Management System standard. Quality Management System requirements for automotive production and relevant service parts organizations. 1st Edition, 1 Octomber 2016.

[4] Gruszka, J., Misztal, A., The new IATF 16949:2016 standard in the automotive supply chain, Research in Logistics \& Production, Vol. 7, No. 4, 311-318, 2017.

[5] Gaikwad, L.M., Sunnapwar, V.K., Teli, S.N. et al. Application of DMAIC and SPC to Improve Operational Performance of Manufacturing Industry: A Case Study, J. Inst. Eng. India Ser. C (2019) 100: 229. https://doi.org/10.1007/s40032-017-0395-5.

[6] P. S. Atigre, A. P. Shah, V. R. Patil, Application of 8D Methodology for Minimizing the Defects in Manufacturing Process: A Case Study, International Journal of Engineering Research \& Technology (IJERT), Vol. 6 Issue 09, 123-126, 2017.

[7] C. A. Riesenberger, S. D. Sousa, The 8D Methodology: An Effective Way to Reduce Recurrence of Customer Complaints? Proceedings of the World Congress on Engineering 2010, Vol III WCE 2010, ISBN: 978-988-18210-8-9, June 30 - July 2, 2010, London, U.K., 2010.

[8] Korenko M., et al: Application 8D method for problems solving, Вісник Львівського національного аграрного університету. Сер: Агроінженерні дослідження, (17) pp. 330-339, 2013.

[9] Misztal A., Grecu I., N. Belu, Customer Satisfaction in the Automotive Industry, Faima Business \& Management Journal VoL.4, Issue 1, March 2016. 